\title{
Trans Fatty Acids in Human Milk in Latvia: Association with Dietary Habits during the Lactation Period
}

\author{
Līva Aumeistere ${ }^{1, *(D)}$, Alīna Beluško ${ }^{1}$, Inga Ciproviča ${ }^{1}$ and Dace Zavadska ${ }^{2}$ \\ 1 Faculty of Food Technology, Latvia University of Life Sciences and Technologies, Rīgas iela 22, \\ LV-3004 Jelgava, Latvia; alinapolipartova@gmail.com (A.B.); inga.ciprovica@llu.lv (I.C.) \\ 2 Department of Pediatrics, Riga Stradinš University, Vienības Gatve 45, LV-1004 Riga, Latvia; \\ dace.zavadska@rsu.lv \\ * Correspondence: aumeistere.liva@gmail.com
}

Citation: Aumeistere, L.; Beluško, A . Ciproviča, I.; Zavadska, D. Trans Fatty Acids in Human Milk in Latvia: Association with Dietary Habits during the Lactation Period. Nutrients 2021, 13, 2967. https://doi.org/ $10.3390 /$ nu13092967

Academic Editor: Megumi Haruna

Received: 1 August 2021

Accepted: 24 August 2021

Published: 26 August 2021

Publisher's Note: MDPI stays neutral with regard to jurisdictional claims in published maps and institutional affiliations.

Copyright: (c) 2021 by the authors. Licensee MDPI, Basel, Switzerland. This article is an open access article distributed under the terms and conditions of the Creative Commons Attribution (CC BY) license (https:// creativecommons.org/licenses/by/ $4.0 /)$.

\begin{abstract}
The human milk fatty acid, including trans fatty acid, composition is predominantly affected by the maternal diet. The aim of this research was to determine the trans fatty acid level in human milk among lactating women in Latvia, and to evaluate how maternal dietary habits affect the trans fatty acid composition of human milk. In total, 70 lactating women participated in this cross-sectional study. A 72-hour food diary and food frequency questionnaire were used to evaluate maternal dietary habits. Different trans fatty acids in human milk samples were determined using gas chromatography (Agilent 6890N, Agilent Technologies Incorporated, the United States). Overall, the dietary intake of trans fatty acids among the participants was $0.54 \pm 0.79 \mathrm{~g}$ per day. The total trans fatty acid level in the human milk samples was $2.30 \% \pm 0.60 \%$. The composition of trans fatty acids found in human milk was associated with maternal dietary habits. Higher elaidic acid, vaccenic acid and total trans fatty acid levels in human milk were found among participants with a higher milk and dairy product intake. Meat and meat product intake were associated with a higher vaccenic acid and total trans fatty acid levels in human milk. A moderate association was also established between maternal trans fatty acid intake and the total trans fatty acid level in human milk. The obtained correlations indicate that maternal dietary habits during lactation can impact the composition of trans fatty acids found in human milk.
\end{abstract}

Keywords: trans fatty acids; human milk; dietary habits; nutrition

\section{Introduction}

Approximately half of infants in Latvia receive human milk for the first six months of life, and for $15-20 \%$ of them, human milk is the only nutrient source during this time [1]. Nutrients for human milk are derived from maternal body stores and those absorbed directly from the maternal diet [2]. Therefore, a well-balanced diet during lactation is important, both for the mother and breastfed infant [2].

There are the following two sources of fatty acids in human milk depending on the length of fatty acids:

- fatty acids up to 14 carbon atoms are synthesised from the glucose via pentose phosphate cycle within the mammary glands;

- long-chain fatty acids ( $\geq \mathrm{C} 16)$ are derived from the maternal bloodstream, and they are transported into lactocytes via the protein-mediated membrane transport system [2].

Therefore, the fatty acid $(\geq \mathrm{C} 16)$ composition of human milk is variable and impacted by maternal dietary habits during lactation [2]. For example, we have previously reported that fish intake reflects on the docosahexaenoic acid level in human milk among lactating women from Latvia [3].

Human milk can also contain a variable amount of trans fatty acids, which may come from the following two dietary sources: 
- natural-via biohydrogenation in the rumen (meat, milk and dairy products). Dominant trans fatty acids from natural food sources are vaccenic acid (C18:1 n11t) and conjugated linoleic acid (main isomer-rumenic acid, C18:2 n9c, n11t);

- industrially - via frying, grilling or the hydrogenation of oils (confectionary, bakery goods, French fries, etc.). The dominant trans fatty acids from industrially produced foodstuff are elaidic acid (C18:1 n9t) and linolelaidic acid (C18:2 n9t, n12t) [4,5].

Trans fatty acids can have a harmful effect on the development of an infant. A higher trans fatty acid level in the body interferes with the desaturation of linoleic acid and $\alpha$ linolenic acid [6]. This could lead to lower levels of arachidonic acid and docosahexaenoic acid in the body, respectively. Both are important fatty acids for the normal development of the brain and eyesight [6]. These negative effects are associated with trans fatty acids that are derived from partially hydrogenated vegetable oils or grilled, fried foods [7]. Opposingly, natural trans fatty acids are associated with health-related benefits [8]. Some researchers have observed that a higher level of natural trans fatty acids in human milk was related to a lower risk of atopic dermatitis, eczema and food allergies for the infant [9]. A possible explanation of this observation is that natural trans fatty acids, such as conjugated linoleic acid, modulate immune function in the human body by reducing the production of pro-inflammatory mediators (cytokines, prostaglandins, etc.) [10].

The current general position is that the human body cannot synthesise trans fatty acids; therefore, the only source for trans fatty acids found in human milk can be the maternal diet [11], but some studies indicate that vaccenic acid can be converted to rumenic acid $(\mathrm{C} 18: 2 \mathrm{n} 9 c, \mathrm{n} 11 t)$ by $\Delta 9$-desaturase in the mammary glands during lactation $[5,12]$.

Current legislation for the Member States of the European Union, including Latvia [13,14], declares the maximum permitted amount of trans fatty acids in food products other than the trans fatty acids naturally occurring in fat of animal origin. The maximum permitted amount shall not exceed $2 \mathrm{~g}$ per $100 \mathrm{~g}$ of fat.

As human milk is the sole source of nutrition for $15-20 \%$ of infants in Latvia in the first six months of life [1], the quality of human milk is of great importance. Therefore, the aim of this research was to determine the trans fatty acid level in human milk among lactating women in Latvia, and to evaluate how maternal dietary habits affect the trans fatty acid composition of human milk.

\section{Materials and Methods}

This cross-sectional study was conducted during the period January till December year 2020. The inclusion criteria for participants were as follows:

1. a signed consent form;

2. residing in Latvia during the study period;

3. singleton pregnancy;

4. at least one month postpartum;

5. exclusively or partially breastfeeding.

The study was conducted in accordance with the Declaration of Helsinki, and prior, approval from the Riga Stradinš University Ethics Committee was obtained (protocol code 6-1/01/6). Written consent was obtained from all the participants before the study. Exclusion criteria for the study were unsigned consent form and/or non-compliance with the inclusion requirements.

In total, 70 participants completed the study. Initially, 108 participants met the study inclusion criteria; however, 38 dropped out.

\subsection{Collection of Human Milk Samples, Food Data and Other Information}

Women were invited to participate in the study using a poster published on social media member groups for lactating mothers. If a woman met the study inclusion criteria, she met with the researcher (in a location convenient for the participant, for example, at home). During the meeting, study materials and a sample container for human milk collection were provided. If necessary, the researcher answered the participant's questions. 
However, if it was more convenient for the participant or due to safety reasons raised by the COVID-19 pandemic, study materials and sample container were sent to the participant using a parcel machine, and all communication between the researcher and a participant was provided electronically.

After receiving the study materials, participants were instructed to choose four consecutive days to carry out the study. Women were able to complete the study in a location convenient for them (for example, at home). Participants were asked to complete a 72-h food diary and provide at least $10 \mathrm{~mL}$ of pooled human milk sample within a 24-h period (milk expressed from the feeding breast after the end of nursing, expressed from various breastfeeding sessions). During the sampling process, participants were instructed to store a prelabelled propylene container with expressed human milk in the refrigerator $\left(\sim 4^{\circ} \mathrm{C}\right)$. After, it was placed in the household freezer (approximately $-18^{\circ} \mathrm{C}$ ).

Participants were also asked to complete a self-administered food frequency questionnaire (FFQ) at any convenient time during the four days of the study period. The FFQ consisted of 71 food products and drinks for which the frequency of consumption was estimated by the participants (participants had to mark how frequently specific products had been consumed one month before participating in the study). All food products and drinks in the FFQ were divided into 15 categories and median intake values for these food products and drinks categories were after evaluated. The categories were the following:

- $\quad$ starchy foods (cereals, cereal products, potatoes);

- meat and meat products;

- fish and seafood;

- milk and dairy products;

- vegetables;

- legumes;

- fruits and berries;

- plant-based fats (nuts, seeds, vegetable oils, avocado);

- condiments (sauces, etc.);

- sweets and bakery goods;

- $\quad$ salty snacks and fast food;

- $\quad$ soft drinks;

- caffeine-containing drinks (coffee, black or green tea, etc.);

- herbal teas;

- alcohol.

No dietary restrictions were applied, and participants were encouraged to consume their regular diet. Volume measures (handful, teaspoon, etc.) could be used to help complete the 72-h food diary.

Demographic characteristics such as maternal age; body mass index; parity; time postpartum; child sex, birth weight and length; and breastfeeding pattern (exclusive or partial) were collected using a self-administered questionnaire undertaken during the four-day study period.

A second visit was arranged after participants had completed the required tasks. During a second meeting (on-site), the researcher collected all the study materials (the completed 72-h diary, FFQ, etc.) and a human milk sample from each participant. A bag with ice packs was used to transport frozen human milk samples to the laboratory's freezer where they were stored until the analysis $\left(-18 \pm 3^{\circ} \mathrm{C}\right)$.

The current Latvian Food composition database lacks dietary data regarding the fatty acid composition of different food products. Therefore, the Finnish Food Composition Database Fineli [15] was used to calculate energy value, protein, carbohydrates, fibre, sugars, fat and fatty acids, including trans fatty acids, intake among the study participants. If a participant was using dietary supplements during the study period, nutritional information was sourced from the manufacturers' website and included in nutrient calculations. 


\subsection{Analysis of Human Milk Samples}

All samples were analysed within two months of arrival at the laboratory. Before the analysis, frozen samples were thawed in warm water $\left(\sim 55^{\circ} \mathrm{C}\right)$ and homogenised using Vortex (VXMNDG Vortex Mini digital, OHAUS Corporation, Parsippany, NJ, USA).

An in-house method BIOR-T-012-131-2011 (developed based on standards ISO 129661:2014, ISO 12966-2:2017 and ISO 12966-4:2015) was used to determine the following trans fatty acids in human milk samples:

- $\quad$ elaidic acid (C18:1 n9t);

- $\quad$ vaccenic acid (C18:1 n11t);

- linolelaidic acid (C18:2 n9t, n12t);

- $\quad$ rumenic acid $(\mathrm{C} 18: 2 \mathrm{n} 9 \mathrm{c}, \mathrm{n} 11 t)$.

Samples $(10.00 \mathrm{~g})$ were weighted in 50-millilitre polypropylene test tubes with screw caps. Fats were extracted with $20 \mathrm{~mL}$ of hexane/acetone (1:1) solution. After, the mixture was mixed for 30 min using a rotator (Multi RS-60 Biosan, Rīga, Latvia) and centrifuged (3500 rpm, $10 \mathrm{~min}$ ) (CM-6MT, Elmi, Newbury Park, CA, USA) to separate the layers of the solution. Approximately $10 \mathrm{~mL}$ of the upper layer of the solution was transferred into a 15 -millilitre propylene screw cup test tube and evaporated with nitrogen $\left(45^{\circ} \mathrm{C}\right)$. Then, $100 \mu \mathrm{L}$ of concentrated residue was transported into a 22-millilitre glass tube and dissolved in $2 \mathrm{~mL}$ of isooctane. To this, $200 \mu \mathrm{L}$ of sodium methoxide was added, and the solution was mixed twice (for $20 \mathrm{~s}$ each time, with 30 to $60 \mathrm{~s}$ pause between) using a vortex mixer (Maxi Mix II Thermo Fisher Scientific, Waltham, MA, USA). The solution was then rested for 1 to $2 \mathrm{~min}$, and after, $2 \mathrm{~mL}$ of sodium chloride solution (40\%) was added. After, the solution was mixed for one more time (20 to $30 \mathrm{~s}$ using a vortex mixer) and centrifuged (2500 rpm, $5 \mathrm{~min}$ ). In the 250-microlitre autosampler container, $150 \mu \mathrm{L}$ of isooctane and $50 \mu \mathrm{L}$ of the organic layer were transported. Then, $20 \mu \mathrm{L}$ of the aliquot was transferred into a 1.5-millilitre glass vial and evaporated with nitrogen $\left(45^{\circ} \mathrm{C}\right)$. The dry residue was reconstructed with $100 \mu \mathrm{L}$ of hexane.

The Discovery ${ }^{\circledR} \mathrm{Ag}$-Ion SPE column, $750 \mathrm{mg} / 6 \mathrm{~mL}$ (Sigma Aldrich Company, St. Louis, MO, USA) was conditioned with $4 \mathrm{~mL}$ of acetone and equilibrated with $4 \mathrm{~mL}$ of hexane. The $100 \mu \mathrm{L}$ of prepared fatty acid methyl ester extract in hexane were loaded on the column. Fraction one was eluated with $6 \mathrm{~mL}$ of hexane:acetone (96:4) and eluant collected using a 15-millilitre propylene tube. This fraction contained saturated fatty acids and trans monounsaturated fatty acids. Fraction two was eluated with $4 \mathrm{~mL}$ of hexane:acetone (90:10) and eluant collected using a 15-millilitre propylene tube. This fraction contained cis monounsaturated fatty acids and trans polyunsaturated fatty acids. Fraction three was eluated with $4 \mathrm{~mL}$ of acetone $(100 \%)$ and eluent was collected using a 15-millilitre propylene tube. This fraction contained all other polyunsaturated fatty acids. Each fraction was evaporated with nitrogen over a water bath (Biosan, Latvia) $\left(40^{\circ} \mathrm{C}\right)$. The dry residue was reconstituted in $80 \mathrm{~mL}$ of hexane for the final step—gas chromatography analysis.

Fatty acid analysis was conducted using gas chromatography with flame ionisation detection (Agilent 6890N, Agilent Technologies Incorporated, Santa Clara, CA, USA). Aliquots of the fatty acid methyl esters $(1 \mu \mathrm{L})$ were injected at a 50:1 split ratio and at $260^{\circ} \mathrm{C}$ into a Restek's Rt-2560 column $(100 \mathrm{~m} \times 0.25 \mathrm{~mm} \times 0.20 \mu \mathrm{m})$ (Restek Corporation, Bellefonte, PA, USA). The flow rate of the helium carrier gas was $1.0 \mathrm{~mL} \mathrm{~min}^{-1}$. The initial oven temperature of $100{ }^{\circ} \mathrm{C}$ was held for two minutes, then increased to $180{ }^{\circ} \mathrm{C}$ at $4{ }^{\circ} \mathrm{C} \min ^{-1}, 210^{\circ} \mathrm{C}$ at $2{ }^{\circ} \mathrm{C} \min ^{-1}, 223^{\circ} \mathrm{C}$ at $0.8{ }^{\circ} \mathrm{C} \mathrm{min}-1$ and $240{ }^{\circ} \mathrm{C}$ at $20^{\circ} \mathrm{C} \mathrm{min}-1$ and held for another ten minutes (total time $64.1 \mathrm{~min}$ ). The detector temperature was $250^{\circ} \mathrm{C}$, $\mathrm{H}_{2}$ flow-40 $\mathrm{mL} \mathrm{min}^{-1}$, airflow- $450 \mathrm{~mL} \mathrm{~min}^{-1}$.

Using authentic standards (Supelco 37 component FAME mix, Supelco Incorporated, Germany and additionally vaccenic acid and rumenic acid standards from Sigma Aldrich Company, St. Louis, MO, USA), the fatty acid methyl esters release times were determined. After, the fatty acid methyl esters chromatographic peaks were identified in the analysis of human milk samples. All identified fatty acid methyl esters peak areas were determined, expressing them as a percentage of the peak area of the sum of all peak areas $(\%$, in total 
38 fatty acids were analysed). The mean value of two parallel repetitions of the analysis was accepted as the final result.

\subsection{Statistical Analysis of the Data}

All data were compiled using Microsoft Excel 2019 and after, International Business Machines (IBM) Statistical Package for the Social Sciences (SPSS), version 23, was used for data statistical analysis. All values were expressed as median \pm interquartile range and minimal-maximal values. Spearman's rank order correlation ([yellow $] \rho$ ) was used to measure correlations between the trans fatty acid level in human milk and maternal dietary habits. A $p$-value of $\leq 0.05$ was considered statistically significant.

\section{Results}

\subsection{Characteristics of the Participants}

The characteristics of the participants are compiled in Tables 1 and 2. According to body mass index calculations, 55 participants had a normal body weight, 12 participants were overweight and 3 participants were obese. Half of the participants $(46 \%)$ were primiparas. Almost all the participants $(97 \%)$ had a child younger than one year old.

Table 1. Maternal characteristics.

\begin{tabular}{cc}
\hline Characteristics & $\begin{array}{c}\text { Median } \pm \text { Interquartile Range } \\
\text { (Minimal-Maximal Values) }\end{array}$ \\
\hline Age (years) & $31 \pm 7(23-45)$ \\
Maternal body mass index & $22.28 \pm 3.79(18.51-36.57)$ \\
Parity & $2 \pm 1(1-5)$ \\
Breastfeeding pattern & 48 -exclusive breastfeeding, \\
22-partial breastfeeding
\end{tabular}

1 calculation based on weight and height values given by the participant. No anthropometrical measures were performed during this study.

Table 2. Child's characteristics.

\begin{tabular}{cc}
\hline Characteristics & $\begin{array}{c}\text { Median } \pm \text { Interquartile Range } \\
\text { (Minimal-Maximal Values) }\end{array}$ \\
\hline Age (months) & $3 \pm 4(1-27)$ \\
Sex & 34 -females, 36-males \\
Birth weight $(\mathrm{kg})$ & $3.61 \pm 0.64(1.63-5.50)$ \\
Birth length $(\mathrm{cm})$ & $54 \pm 3(42-61)$ \\
\hline
\end{tabular}

\subsection{Dietary Habits and Nutrient Intakes among the Participants}

The evaluation of FFQ revealed that important food product groups such as starchy foods, vegetables, etc. were not consumed on a daily basis (Figure 1).

For example, only $27 \%$ of the participants consumed starchy foods such as cereals, cereal products and potatoes daily. Meat \& meat products were consumed every other day by $29 \%$ of the participants. Around $30 \%$ of the participants consumed milk and dairy products every or every other day. Approximately $20 \%$ of the participants completely avoided milk and dairy products during the lactation period. The main reason for this was an infant having a cow's milk protein allergy (10\% of the participants). Other reasons were vegetarian or vegan dietary patterns ( $4 \%$ of the participants). The remaining participants $(6 \%)$ did not state why milk and dairy products were avoided.

Fish and seafood was avoided (17\% of the participants) or consumed rarely ( $57 \%$ of the participants). Vegetables and legumes were consumed on a daily basis by 6 and $10 \%$ of the participants, respectively. Fruits and berries were consumed every other day by $13 \%$ of the participants, but plant-based fats (nuts, seeds, vegetable oils, etc.) were consumed on a daily basis by $19 \%$ of the participants. Condiments were mostly consumed seldomly ( $41 \%$ of the participants). Half of the participants consumed sweets and baked goods seldomly 
and $60 \%$ consumed salty snacks and fast foods seldomly. Most of the participants (56\%) avoided soft drinks, but caffeine-containing drinks or herbal teas were mostly consumed on a daily basis ( 26 and $41 \%$ of the participants, respectively). Most of the participants $(79 \%)$ reported an avoidance of alcohol during the lactation period.

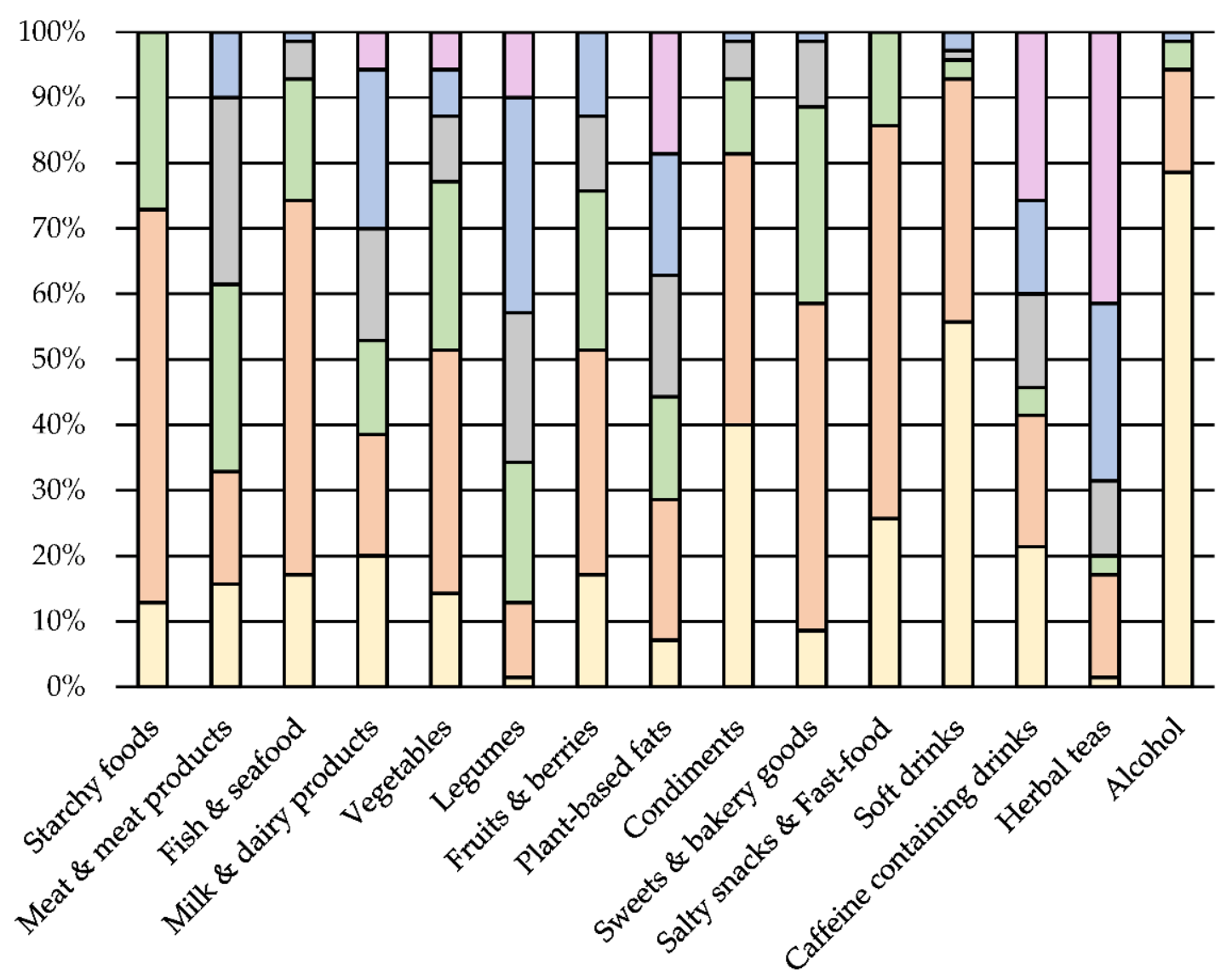

$\square$ Never $\square$ Seldom $\square$ Once a Week $\square$ Twice a Week $\square$ Almost every Day $\square$ Every Day

Figure 1. Median intake frequency of food products and drinks one month before participating in the study.

The median energy and nutrient intakes calculated from the 72-hour food diaries are summarised in Table 3.

If compared to nutritional guidelines (Table 3), the participants were consuming less energy and carbohydrates than recommended. Additionally, fibre intake was a little lower than recommended. Sugar intake compiled around $16 \%$ of total energy intake, and fat intake was higher than recommended. Protein intake was within nutritional guidelines.

Saturated fatty acid consumption exceeded $10 \%$ of total energy intake. Monounsaturated and polyunsaturated fatty acid intake was within recommendations. Linoleic acid consumption exceeded $4 \%$ of total energy intake. $\alpha$-linolenic acid and total $n-3$ polyunsaturated fatty acid consumption reached the recommended intake of at least 0.5 and $1 \%$ of total energy, respectively. Median daily docosahexaenoic acid intake reached only $50 \%$ of the recommended daily intake. 
Table 3. Daily energy and nutrient intakes in comparison to nutritional guidelines (median values from 72-h food diary).

\begin{tabular}{|c|c|c|}
\hline Energy Value or Nutrient (Unit) & $\begin{array}{l}\text { Median } \pm \text { Interquartile Range } \\
\text { (Minimal-Maximal Values) }\end{array}$ & Nutritional Guidelines \\
\hline Energy value (kcal) & $\begin{array}{l}2007.42 \pm 498.31 \\
(827.09-3191.99) \\
\end{array}$ & $2340-3110 \mathrm{kcal}[16]$ \\
\hline Protein $(\mathrm{E} \%)$ & $15.52 \pm 5.80(8.01-43.08)$ & $10-20 \mathrm{E} \%[16,17]$ \\
\hline Carbohydrates (E\%) & $38.81 \pm 8.38(11.90-52.79)$ & $45-60 \mathrm{E} \%[16,17]$ \\
\hline Sugars (E\%) & $16.15 \pm 6.85(0.93-27.94)$ & $\leq 10 \mathrm{E} \%$ (free sugars) $[16,17]$ \\
\hline Fibre (g) & $22.72 \pm 12.01(7.05-48.84)$ & at least $25-35 \mathrm{~g}$ [17] \\
\hline Fat, total $(\mathrm{E} \%)$ & $42.69 \pm 8.63(29.78-56.79)$ & $\begin{array}{l}25-30 \text { E\% [16] } \\
25-35 \text { E\% [18] } \\
25-40 \text { E\% [17] }\end{array}$ \\
\hline Saturated fatty acids (E\%) & $14.09 \pm 6.62(5.45-20.77)$ & $\begin{array}{l}\leq 10 \mathrm{E} \%[16,17] \\
\text { As low as possible [18] }\end{array}$ \\
\hline $\begin{array}{l}\text { Monounsaturated } \\
\text { fatty acids (E\%) }\end{array}$ & $15.61 \pm 4.29(9.32-27.79)$ & $10-20 \mathrm{E} \%[17]$ \\
\hline $\begin{array}{c}\text { Linoleic acid } \\
(\mathrm{C} 18: 2, n-6)(\mathrm{E} \%)\end{array}$ & $5.40 \pm 2.95(2.37-17.46)$ & $4 \mathrm{E} \%[18]$ \\
\hline $\begin{array}{c}\alpha \text {-linolenic acid } \\
(\mathrm{C} 18: 3, n-3)(\mathrm{E} \%)\end{array}$ & $1.07 \pm 0.71(0.33-3.16)$ & at least $0.5 \mathrm{E} \%[17,18]$ \\
\hline $\begin{array}{l}\text { Eicosapentaenoic acid (C20:5, } \\
n-3)(\mathrm{mg})\end{array}$ & $18.01 \pm 255.35$ (0.00-1222.69) & no guidelines \\
\hline $\begin{array}{c}\text { Docosahexaenoic acid (C22:6, } \\
n-3)(\mathrm{mg})\end{array}$ & $\begin{array}{c}117.87 \pm 234.39 \\
(0.00-3369.78)\end{array}$ & $200 \mathrm{mg}$ [17] \\
\hline $\begin{array}{l}n-3 \text { polyunsaturated } \\
\text { fatty acids }(\mathrm{E} \%)\end{array}$ & $1.20 \pm 0.95(0.11-5.51)$ & at least $1 \mathrm{E} \%$ [17] \\
\hline $\begin{array}{l}n-6 \text { polyunsaturated } \\
\text { fatty acids (g) }\end{array}$ & $12.44 \pm 6.74(2.93-34.06)$ & no guidelines \\
\hline $\begin{array}{c}\text { Polyunsaturated } \\
\text { fatty acids (E\%) }\end{array}$ & $7.00 \pm 3.53(3.73-17.92)$ & 5-10 E\% [16,17] \\
\hline Trans fatty acids (g) & $0.54 \pm 0.79(0.00-1.82)$ & $\begin{array}{c}\text { as low as possible } \\
{[17,18]}\end{array}$ \\
\hline
\end{tabular}

No specific values have been set regarding recommended trans fatty acid intake during lactation, but both Nordic Nutrition guidelines [17] and European Food Safety Authority scientific opinion [18] suggest that the trans fatty acid intake during lactation should be as low as possible.

Maternal trans fatty acid intake was significantly higher among those with higher intakes of milk and dairy products $(\rho=0.372, p=0.003)$ and sweets and bakery goods $(\rho=0.305, p=0.017)$. Opposingly a significantly lower intake of trans fatty acids was noted among the participants with a higher intake of vegetables $(\rho=-0.336, p=0.008)$ and legumes $(\rho=-0.262, p=0.041)$.

\subsection{Trans Fatty Acid Level in Human Milk}

The median \pm interquartile range, as well as the minimal-maximal values of the trans fatty acids level in human milk samples are summarised in Table 4.

Vaccenic acid was the most predominant trans fatty acid found in human milk, compiling approximately $70 \%$ of total trans fatty acids. There was a significant positive correlation found between elaidic acid and rumenic acid $(\rho=0.331, p=0.009)$ as well as linolelaidic acid and rumenic acid $(\rho=0.462, p<0.0005)$ level in human milk. 
Table 4. Trans fatty acid level (\% of total fatty acids) in human milk.

\begin{tabular}{cc}
\hline Trans Fatty Acids & $\begin{array}{c}\text { Median } \pm \text { Interquartile Range } \\
\text { (Minimal-Maximal Values) }\end{array}$ \\
\hline Elaidic acid $(\mathrm{C} 18: 1 \mathrm{n} 9 t)$ & $0.50 \pm 0.40(0.10-1.40)$ \\
Vaccenic acid $(\mathrm{C} 18: 1 \mathrm{n} 11 t)$ & $1.70 \pm 0.50(0.90-2.20)$ \\
Linolelaidic acid $(\mathrm{C} 18: 2 \mathrm{n} 9 t, \mathrm{n} 12 t)$ & $0.10 \pm 0.10(<0.10-0.30)$ \\
Rumenic acid $(\mathrm{C} 18: 2 \mathrm{n} 9 c, \mathrm{n} 11 t)$ & $0.10 \pm 0.10(<0.10-0.30)$ \\
Trans fatty acid, total $^{1}$ & $2.30 \pm 0.60(1.00-3.20)$ \\
\hline 1
\end{tabular}

${ }^{1}$ Rumenic acid is not included in the sum of total trans fatty acids [19].

\subsection{Trans Fatty Acid Level in Human Milk and Its Relation to Maternal Dietary Habits}

A strong positive correlation was found for milk and dairy product intake and elaidic acid level in human milk $(\rho=0.632, p<0.0005)$. Vaccenic acid level was associated with meat and meat products $(\rho=0.348, p=0.006)$ and milk and dairy products intake $(\rho=0.277$, $p=0.031$ ). Total trans fatty acid level was related to the habitual intake of meat and meat products $(\rho=0.296, p=0.021)$ and milk and dairy products $(\rho=0.566, p<0.0005)$. There was a moderate direct association between maternal trans fatty acid intake and total trans fatty acid level in human milk $(\rho=0.341, p=0.007)$.

\section{Discussion}

The content of trans fatty acids in natural products and, therefore, the intake of naturally occurring trans fatty acids is relatively constant $[4,13]$. On the other hand, the intake of industrially produced trans fatty acids within the European Union has been gradually decreasing due to the regulation rules setting the maximum permitted amount of trans fatty acids in food products $[13,14,19]$. Due to the new regulations, industrially produced food products have been reformulated and ingredients such as partially hydrogenated fats replaced, mainly with palm oil [13].

Additionally, this study shows a low trans fatty acid intake among lactating women (Table 5). This could be due to the above-mentioned changes in European legislation, which, therefore, now results in a lower total intake of trans fatty acids among lactating women in Europe.

Table 5. Trans fatty acid intake (g per day) among lactating women. Data from different countries.

\begin{tabular}{cccc}
\hline Latvia $(\boldsymbol{n}=\mathbf{7 0})$ & Romania $(\boldsymbol{n}=\mathbf{3 3})$ [20] & Croatia $(\boldsymbol{n}=\mathbf{8 3})$ [21] & Poland $(\boldsymbol{n}=\mathbf{6 9})$ [11] \\
\hline $\begin{array}{c}0.54 \pm 0.79 \\
(0.00-1.82)\end{array}$ & $\begin{array}{c}0.95 \\
(0.81-1.07)\end{array}$ & $2.00 \pm 0.90$ & $5.76 \pm 2.77$ \\
\hline
\end{tabular}

Overall, the trans fatty acid intake among lactating women in Europe has not been comprehensively analysed in the past decade. Few studies that have been conducted differ in methodology and have low participant numbers ( $<100$ participants) (Table 5). Therefore, data can only be compared in the context of the significant reduction in the trans fatty acid content of the food due to legislation changes and, therefore, result in the lower consumption of trans fatty acids among lactating women in Europe.

According to the obtained correlations, the trans fatty acid intake in this study was related to both milk and dairy products and sweet and bakery goods intake. Researchers from Croatia [21] also found results, identifying that the dominant dietary sources of trans fatty acids among lactating women were sweets and bakery goods and milk and dairy products.

Not only trans fatty acid intake, but also trans fatty acid composition among lactating women in Europe has not been comprehensively analysed in recent years (Table 6). Therefore, it is not possible to compare the data. However, overall, the total trans fatty acid level in human milk among lactating women from Europe is lower than the data reported from the United States (Table 6). Referring to the results from this study and taking into 
account the recent legislation changes in the European Union, it can be speculated that the trans fatty acid intake as well as the trans fatty acid levels in human milk among lactating women in Europe has likely decreased in the past few years.

Table 6. The trans fatty acid level (\% of total fatty acids) in human milk. Data from different countries.

\begin{tabular}{cccccc}
\hline $\begin{array}{c}\text { Trans Fatty } \\
\text { Acids }\end{array}$ & $\begin{array}{c}\text { Latvia } \\
(\boldsymbol{n}=\mathbf{7 0 )}\end{array}$ & $\begin{array}{c}\text { The Netherlands }(\boldsymbol{n}=\mathbf{1 8 6}, \\
\text { Conventional Diet Group) [22] }\end{array}$ & $\begin{array}{c}\text { Germany } \\
(\boldsymbol{n}=\mathbf{4 0 )}[23]\end{array}$ & $\begin{array}{c}\text { Greece } \\
(\boldsymbol{n}=\mathbf{1 2 7})[24]\end{array}$ & $\begin{array}{c}\text { The United States } \\
(\boldsymbol{n}=\mathbf{8 1})[25]\end{array}$ \\
\hline Elaidic acid & $0.50 \pm 0.40$ & $0.61 \pm 0.27$ & $0.34 \pm 0.14$ & $0.57 \pm 0.38$ & $0.65 \pm 0.25$ \\
Vaccenic acid & $1.70 \pm 0.50$ & $0.48 \pm 0.21$ & $0.68 \pm 24$ & No data & $0.04 \pm 0.01$ \\
Linolelaidic acid & $0.10 \pm 0.10$ & No data & $0.12 \pm 0.08$ & $0.11 \pm 0.17$ & $0.91 \pm 0.28$ \\
Rumenic acid & $0.10 \pm 0.10$ & $0.25 \pm 0.07$ & $0.40 \pm 0.09$ & No data & $0.43 \pm 0.10$ \\
Trans fatty acids, total ${ }^{1,2}$ & $2.30 \pm 0.60$ & $3.26 \pm 1.06$ & $3.81 \pm 0.97$ & $0.68 \pm 0.44$ & $7.00 \pm 2.30$ \\
\hline
\end{tabular}

${ }^{1}$ Rumenic acid is not included in the sum of total trans fatty acids [19]. ${ }^{2}$ Not all individual trans fatty acids are reported in the table; therefore, the total trans fatty acid level may be higher than the total sum of individual trans fatty acids reported in the table.

Previous studies have indicated that vaccenic acid can be converted to the rumenic acid in the mammary glands during lactation $[5,12]$. Nevertheless, the conversion rate is low, with less than $10 \%$ of the rumenic acid coming from the endogenous synthesis of vaccenic acid [5]. This could explain why no significant correlation between the vaccenic acid and rumenic acid levels in human milk was found in this study.

Vaccenic acid is the predominant trans fatty acid found in animal origin fat [4]. Therefore, the strong positive association in this study between vaccenic acid levels and the intake of meat and meat products and milk and dairy products was not surprising. Although, it should be noted that the overall milk and dairy products and meat and meat products intake among the participants was not high, with the majority of participants consuming these food products only a few times a week. Approximately $20 \%$ of participants completely avoided milk and dairy products during the lactation period (Figure 1). This was predominately due to infants having a cow's milk protein allergy.

Precht and Molkentin (1999) [23] have also observed a higher vaccenic acid level in human milk among German lactating women with a higher consumption of milk and dairy products. A study from the Netherlands [22] suggests that a maternal diet rich in meat and dairy products (especially organically produced) is associated with a lower elaidic acid/vaccenic acid ratio in human milk (ratio of 1.27 for conventional diets versus the ratio of 0.86 for a diet rich in organically produced meat and dairy products). Although milk and dairy products, as well as meat and meat products, intake was not high, this study reports a lower elaidic/vaccenic acid ratio in human milk of 0.29 compared to the study from the Netherlands [22].

Although a higher elaidic acid intake and, therefore, a higher elaidic acid level in human milk is usually associated with industrially produced food products such as sweets and bakery goods intake [4,25], in this study, a higher elaidic acid level in human milk was associated with milk and dairy product intake. This obtained correlation could be explained by the fact, that cow's milk can also contain traces of elaidic acid, and its content can increase with the heat treatment of milk [26].

A higher rumenic acid level in human milk $(0.34 \%)$ has been reported among lactating women who are predominantly consuming meat and dairy products of organic origin compared to women on conventional diets $(0.25 \%)$ [27]. Data were not collected to determine if participants consumed conventional or organically produced ruminant products in this study, but we speculate that participants were mostly consuming conventionally produced meat and meat products and milk and dairy products. Additionally, within this study, the FFQ results suggested that women less frequently consumed milk and dairy products as well as meat and meat products. This could potentially explain why lower rumenic acid levels are reported when compared to data from other countries (Table 6).

Similar to observations reported from other countries $[10,21,23]$, this study also reports that the trans fatty acid level in human milk is directly linked to the maternal dietary intake 
of trans fatty acids. However, it seems that the trans fatty acid level in human milk among lactating women in Latvia is more closely related to the intake of ruminant fat (milk and dairy products and meat and meat products). This differs from previous studies that have found that trans fatty acid levels in human milk were related to the intake of sweets and bakery items in Polish women [11] and sweets, bakery goods, fried food, dairy products, margarine and sausages in Croatian women [21]. Other studies [28] have not observed a direct link between the maternal intake of trans fatty acids during lactation and their level in human milk.

Obtained results indicate that maternal dietary habits during lactation are an important factor influencing the quality of the nutrition received by the infant via human milk. Women from Latvia during the lactation period are predominantly consuming trans fatty acids of natural sources (ruminant food products). Thanks to the national legislation rules in Latvia [14], women are able to choose industrially produced foodstuff without a high amount of trans fatty acids, which can have an adverse effect both on the mother and the infant.

Nevertheless, there are currently no nutritional guidelines in Latvia for women during their lactation period. To increase awareness of women's nutritional needs during the lactation period, the national authorities of Latvia could adopt dietary guidelines that encourage women to consume more milk and dairy products (preferably organically produced), to increase the conjugated linoleic acid level in human milk, potentially providing further health benefits to the breastfed infant.

\section{Conclusions}

The dietary data suggest that the trans fatty acid intake among lactating women in Latvia is generally low and does not raise concern. This is probably due to the regulation rules in the Europe Union setting the maximum permitted amount of trans fatty acids in food products. Vaccenic and elaidic acid were the most predominant trans fatty acids in human milk, which was largely determined by the consumption of milk and dairy products.

Author Contributions: Conceptualisation, L.A.; design, L.A.; methodology, L.A.; collection of 72 hour food diaries, L.A. and A.B.; inspection and analysis of the food records, L.A.; data analysis and interpretation, L.A.; writing-original draft preparation, L.A.; supervision, I.C. and D.Z. All authors have read and agreed to the published version of the manuscript.

Funding: This research was funded by THE LATVIA UNIVERSITY OF LIFE SCIENCES AND TECHNOLOGIES, Contract No. 3.2-10/2019/LLU, Project No. G1.

Institutional Review Board Statement: The study was conducted according to the guidelines of the Declaration of Helsinki and approved by the Riga Stradinš University Ethics Committee on 30 January 2020 (protocol code 6-1/01/6).

Informed Consent Statement: Informed consent was obtained from all the participating women involved in the study.

Acknowledgments: Gratitude to all the participating women who donated human milk samples for the study.

Conflicts of Interest: This study has received a grant from the Latvia University of Life Sciences and Technologies (Contract No. 3.2-10/2019/LLU, Project No. G1). I.C. and L.A. are working at the Latvia University of Life Sciences and Technologies, but A.B. was a student at Latvia University of Life Sciences and Technologies. The funders had no role in the design of the study; in the collection, analyses, or interpretation of data; in the writing of the manuscript, or in the decision to publish the results. D.Z. declares no conflict of interest.

\section{References}

1. Slimību Profilakses un Kontroles Centrs. Statistikas Dati par Bērnu Veselību, 2010-2018. Gads. Available online: https: //www.spkc.gov.lv/lv/statistikas-dati (accessed on 15 August 2021).

2. Hale, T.W.; Hartmann, P.E. Textbook of Human Lactation, 1st ed.; Springer Publishing Company: New York, NY, USA, 2017; pp. 371-386. 
3. Aumeistere, L.; Ciproviča, I.; Zavadska, D.; Volkovs, V. Fish intake reflects on DHA level in breast milk among lactating women in Latvia. Int. Breastfeed. J. 2018, 13, 33. [CrossRef] [PubMed]

4. Craig-Schmidt, M.C. World-Wide Consumption of Trans Fatty Acids. Atheroscler. Suppl. 2006, 7, 1-4. [CrossRef] [PubMed]

5. Mosley, E.E.; McGuire, M.K.; Williams, J.E.; McGuire, M.A. Cis-9, Trans-11 Conjugated Linoleic Acid Is Synthesized from Vaccenic Acid in Lactating Women. J. Nutr. 2006, 136, 2297-2301. [CrossRef] [PubMed]

6. Mennitti, L.V.; Oliveira, J.L.; Morais, C.A.; Estadella, D.; Oyama, L.M.; Oller do Nascimento, C.M.; Pisani, L.P. Type of fatty acids in maternal diets during pregnancy and/or lactation and metabolic consequences of the offspring. J. Nutr. Biochem. 2015, 26, 99-111. [CrossRef] [PubMed]

7. Islam, A.; Nurul Amin, M.; Siddiqui, S.A.; Hossain, P.; Sultana, F.; Kabir, R. Trans fatty acids and lipid profile: A serious risk factor to cardiovascular disease, cancer and diabetes. Diabetes Metab. Syndr. 2019, 13, 1643-1647. [CrossRef] [PubMed]

8. Den Hartigh, L.J. Conjugated Linoleic Acid Effects on Cancer, Obesity, and Atherosclerosis: A Review of Pre-Clinical and Human Trials with Current Perspectives. Nutrients 2019, 11, 370. [CrossRef] [PubMed]

9. Thijs, C.; Müller, A.; Rist, L.; Kummeling, I.; Snijders, B.E.P.; Huber, M.; van Ree, R.; Simões-Wüst, A.P.; Dagnelie, P.C.; van den Brandt, P.A. Fatty acids in breast milk and development of atopic eczema and allergic sensitisation in infancy. Allergy 2011, 66, 58-67. [CrossRef] [PubMed]

10. Chisaguano, A.M.; Montes, R.; Castellote, A.I.; Morales, E.; Julvez, J.; Vioque, J.; Sunyer, J.; López-Sabater, M.C. Elaidic, vaccenic, and rumenic acid status during pregnancy: Association with maternal plasmatic LC-PUFAs and atopic manifestations in infants. Pediatr. Res. 2014, 76, 470-476. [CrossRef] [PubMed]

11. Mojska, H.; Socha, J.; Soplińska, E.; Jaroszewska-Balicka, W.; Szponar, L. Trans Fatty Acids in Human Milk in Poland and Their Association with Breastfeeding Mothers' Diets. Acta Paediatr. 2003, 92, 1381-1387. [CrossRef] [PubMed]

12. Turpeinen, A.M.; Mutanen, M.; Aro, A.; Salminen, I.; Basu, S.; Palmquist, D.L.; Griinari, J.K. Bioconversion of Vaccenic Acid to Conjugated Linoleic Acid in Humans. Am. J. Clin. Nutr. 2002, 76, 504-510. [CrossRef] [PubMed]

13. World Health Organization. Regional Office for Europe. Eliminating Trans Fats in Europe. A Policy Brief. 2015. Available online: https:/ / www.euro.who.int/_data/assets/pdf_file/0010/288442/Eliminating-trans-fats-in-Europe-A-policy-brief.pdf (accessed on 15 August 2021).

14. Cabinet of Ministers of the Republic of Latvia. Cabinet Regulation No. 301. Regulations Regarding the Maximum Permitted Amount of Trans Fatty Acids in Food Products. Adopted 17 May 2016. Available online: https://likumi.lv/ta/en/en/id/282210 -regulations-regarding-the-maximum-permitted-amount-of-trans-fatty-acids-in-food-products (accessed on 15 August 2021).

15. Nutrition Unit of the National Institute for Health and Welfare. Fineli Food Composition Database, Release 20. 27 June 2019. Available online: https:/ / fineli.fi/fineli/en/tietoa-palvelusta (accessed on 15 August 2021).

16. Veselības Ministrija. Ieteicamās Enerǵijas un Uzturvielu devas Latvijas Iedzīvotājiem. Available online: https://www.spkc.gov. lv/sites/spkc/files/data_content/ieteicams_enerijas_un_uzturvielu_devas1.pdf (accessed on 15 August 2021).

17. Nordic Nutrition Recommandations 2012. Available online: https://norden.diva-portal.org/smash/get/diva2:704251 /FULLTEXT01.pdf (accessed on 15 August 2021).

18. European Food Safety Authority. Dietary Reference Values for EU. Available online: https://efsa.gitlab.io/multimedia/drvs/ index.htm (accessed on 15 August 2021).

19. Regulation (EU) No 1169/2011 of the European Parliament and of the Council of 25 October 2011 on the Provision of Food Information to Consumers, Amending Regulations (EC) No 1924/2006 and (EC) No 1925/2006 of the European Parliament and of the Council, and Repealing Commission Directive 87/250/EEC, Council Directive 90/496/EEC, Commission Directive 1999/10/EC, Directive 2000/13/EC of the European Parliament and of the Council, Commission Directives 2002/67/EC and 2008/5/EC and Commission Regulation (EC) No 608/2004. Available online: https://eur-lex.europa.eu/legal-content/EN/ TXT/?uri=CELEX\%3A02011R1169-20180101\&qid=1629056437646 (accessed on 15 August 2021).

20. Hegheş, S.C.; Gavrilaş, L.I.; Parela, I.E.; Filip, L.; Cozma-Petruţ, A.; Iuga, C.A.; Suharoschi, R.; Miere, D. Evaluation of Energy and Nutrient Intake From Food of Lactating Women in a Romanian Sample. Farmacia 2018, 66, $243-247$.

21. Kresić, G.; Dujmović, M.; Mandić, M.L.; Delaš, I. Dietary and Breast Milk Trans Fatty Acids Seen in Croatian Breastfeeding Women from Adriatic Region. J. Food Nutr. Res. 2013, 52, 156-163.

22. Mueller, A.; Thijs, L.; Rist, L.; Simões-Wüst, A.P.; Huber, M.; Steinhart, H. Trans Fatty Acids in Human Milk are an Indicator of Different Maternal Dietary Sources Containing Trans Fatty Acids. Lipids 2010, 45, 245-251. [CrossRef] [PubMed]

23. Precht, D.; Molkentin, J. C18:1, C18:2 and C18:3 trans and cis fatty acid isomers including conjugated cis delta 9, trans delta 11 linoleic acid (CLA) as well as total fat composition of German human milk lipids. Nahrung 1999, 43, 233-244. [CrossRef]

24. Antonakou, A.; Skenderi, K.P.; Chiou, A.; Anastasiou, C.A.; Bakoula, C.; Matalas, A.L. Breast Milk Fat Concentration and Fatty Acid Pattern During the First Six Months in Exclusively Breastfeeding Greek Women. Eur. J. Nutr. 2013, 52, 963-973. [CrossRef] [PubMed]

25. Mosley, E.E.; Wright, A.L.; McGuire, M.K.; McGuire, M.A. Trans. Fatty Acids in Milk Produced by Women in the United States. Am. J. Clin. Nutr. 2005, 82, 1292-1297. [CrossRef] [PubMed]

26. Salamon, R.V.; Lóki, K.; Salamon, S.; Sára, P.; Albert, B.; Mándoki, Z.; Csapó, J.; Györi, A.; Csapó, J. Changes in fatty acid composition of different milk products caused by different technology. Acta Univ. Sapientiae Aliment. 2009, 2, 101-109. 
27. Rist, L.; Mueller, A.; Barthel, C.; Snijders, B.; Jansen, M.; Simões-Wüst, A.P.; Huber, M.; Kummeling, I.; von Mandach, U.; Steinhart, $\mathrm{H}$; ; et al. Influence of organic diet on the amount of conjugated linoleic acids in breast milk of lactating women in the Netherlands. Br. J. Nutr. 2007, 97, 735-743. [CrossRef] [PubMed]

28. Daud, A.Z.; Mohd-Esa, N.; Azlan, A.; Chan, Y.M. The trans fatty acid content in human milk and its association with maternal diet among lactating mothers in Malaysia. Asia Pac. J. Clin. Nutr. 2013, 22, 431-442. [PubMed] 